\title{
CPE wt Allele
}

National Cancer Institute

\section{Source}

National Cancer Institute. CPE wt Allele. NCI Thesaurus. Code C95808.

Human CPE wild-type allele is located in the vicinity of $4 \mathrm{q} 32.3$ and is approximately $120 \mathrm{~kb}$ in length. This allele, which encodes carboxypeptidase E protein, plays a role in both proteolysis and peptide hormone synthesis. 